\title{
Editorial Nuevos tiempos para la
Revista de Biología Marina y Oceanografía
}

La Revista de Biología Marina y Oceanografía, fundada en 1948, ha publicado ininterrumpidamente un volumen anual en papel, con 3 números por volumen durante sus extensos 65 años de vida. En todo este periodo ha experimentado una serie de cambios en su formato y estructura, adecuándose a las exigencias de los tiempos y también para llegar de mejor forma a las más de 100 universidades, instituciones, museos y sociedades que la reciben en 28 países, por medio de compra directa o de canje. Este fin de año 2013, nuestra Revista cierra un ciclo de publicación en formato impreso, y continúa sólo en formato digital, más acorde con los principios ecológicos y de sustentabilidad de recursos de los tiempos modernos. La digitalización ha supuesto en la actualidad un cambio estructural en el ámbito de las comunicaciones, equivalente al que generase Gutenberg hace más de 5 siglos, con la masificación y perfeccionamiento en el uso de la imprenta.

Estamos conscientes que decir adiós al papel es una instancia difícil para aquella parte de la comunidad académica que suele ser más bien conservadora. Para estos últimos, la revista impresa y su satinado y aromático papel se enmarca en una dimensión romántica que es difícil de emular. No obstante en la actualidad nuestro planeta y sus distintos ecosistemas se encuentran en una muy delicada situación, debido a la sobre explotación de recursos naturales y también producto de la contaminación y daño ambiental. En ambas dimensiones la elaboración de papel produce una importante huella ecológica. La industria papelera es una de las mayores consumidoras de energía y agua, y es el tercer emisor más grande de gases de efecto invernadero. Por otra parte, es sabido que alrededor de un $40 \%$ de la madera talada en el mundo para uso industrial es usada para fabricar papel.

Nuestra revista científica en los últimos 3 años ha tenido una tirada por número de 200 ejemplares, y llegó a producir 500 hace unos 10 años, cuando el papel y costos de transporte eran menores, contándose el volumen de papel utilizado anualmente en centenares de miles de hojas. Dentro de las ventajas que conlleva la edición electrónica de la revista, está que el concepto «tirada de ejemplares» no existe, porque este se asocia a la cantidad de papel utilizado y a los costos de impresión. La cantidad de reproducciones que se pueden hacer de los artículos digitales no tiene límites. En términos económicos y de tiempo la distribución de la revista impresa implica el transporte a cientos y miles de kilómetros de distancia, lo que supone un alto costo y pone en juego una llegada oportuna a destino. La revista digital es accesible con la ventaja de descarga directa y sin costo. Así, en la actualidad la literatura científica llega a más personas debido a la modalidad "Open Access», siendo una herramienta de gran capacidad para la transmisión del conocimiento. Adicionalmente, la inclusión de las direcciones de correo electrónico de los autores permite el contacto directo, el intercambio de información, comentarios, etc. Estos aspectos son fundamentales para la comunidad científica y constituyen sin duda un aporte importante de este sistema de publicaciones en línea.

Esperamos que nuestros suscriptores e investigadores, que nos prefieren para publicar sus artículos y notas científicas, logren la capacidad de ajuste necesaria para asumir este cambio, dado que con el simple hecho de sumarnos, evitando impresiones en papel, promovemos el cuidado de los recursos naturales de nuestro planeta, contribuyendo a su sostenibilidad. 


\section{New times for the Revista de Biología Marina y Oceanografía}

The Revista de Biología Marina y Oceanografía, founded in 1948, has published continuously one printed volume per year, with 3 issues per volume during its extensive 65 years of life. Throughout this period has undergone a series of changes in its format and structure, that has been adapted to the needs of the times and looking for the best way to reach the more than 100 universities, institutions, museums and societies from 28 different countries that receive the journal through direct purchase or exchange. This year 2013 (December issue), our Journal will close this cycle of print publication to follow on just with digital format, more in accordance with ecological principles and sustainability of resources of modern times. Digitalization has made today a structural change in the field of communications, equivalent to that generated by Gutenberg over five centuries ago, with the massive application and improvement in the use of print press.

We are aware that saying goodbye to print publication is a difficult instance for a part of the academic community that tends to be rather conservative. For them, print journal and aromatic satin paper is part of a romantic dimension that is difficult to emulate. But today our planet and its various ecosystems are in a very delicate situation, due to over exploitation of natural resources and pollution and as a result of environmental damage. In both dimensions, papermaking causes significant ecological footprint. The paper industry is one of the largest consumers of energy and water, and is the third largest responsible of emitting greenhouse gases. Moreover, it is known that about $40 \%$ of the wood harvested in the world for industrial utilization is used to make paper.

Into the last three years, our scientific journal has produced a print run of 200 copies per issue, reaching up to 500 copies about 10 years ago, when paper and transport costs were lower, counting the volume of paper used annually in printing on the order of hundreds of thousands of pages. Among the benefits associated with the online edition of the journal, is that the concept of «circulation of print copies» no longer exists, because it is associated with the usage of paper and printing costs. The online dissemination of articles is limitless. Another important reduction in money and time is related to the distribution of the printed copies. Transportation to hundreds and thousands of miles away has a high cost and brings into play a timely arrival at destination. Thus, at present the scientific literature reaches more people due to the mode "Open Access» being currently a tool of great capacity for transferring of knowledge. Additionally, the inclusion of email addresses of the authors allows direct contact, exchange of information, comments, etc. These issues are fundamentals to the scientific community and are undoubtedly an important contribution of online publication system.

We hope that our readers and researchers, who choose our journal to publish their articles and research notes, are already prepared to adjust themselves to this change, since the fact join, avoiding paper prints, promote the care of natural resources of our planet, contributing to its sustainability.

Dr. Ricardo Bravo

Director

Revista de Biología Marina y Oceanografía Facultad de Ciencias del Mar y de Recursos Naturales Universidad de Valparaíso, Valparaíso, Chile ricardo.bravo@uv.cl 